\title{
Evaluation of Viability Encapsulation of Probiotic Cuko Pempek
}

\author{
Mukhtarudin Muchsiri', Basuni Hamzah², Agus Wijaya², dan Rindit Pambayun ${ }^{2}$
}

${ }^{1}$ Lecturer of Study Program of Food Science and Technology Universitas Muhammadiyah Palembang, Indonesia

${ }^{2}$ Lecturer of Doctoral Program of Agricultural Industrial Technology Universitas Sriwijaya palembang, Indonesia

\begin{abstract}
The purpose of this research made Cuko Pempek as functional food by supplementing BAL to produce Cuko pempek probiotic. The existence of anti-microbial and antibacterial Cuko pempek components became obstacles, therefore it needed strategy to answer two main issues that was first, still allowe the existence of capsaicin and alisin which was caracter impact of Cuko pempek; and second, to protect BAL in order to survive. The strategy was the encapsulation prepared according to Sheu and Marshall, (1993) and the preparation of Cuko pempek modified from $I D$, (2012). The result showed that the encapsulation of Cuko pempek probiotic with cold storage at temperature of $12^{\circ} \mathrm{C}$ produced viability with the average number of cells reaching the range of $10^{9}, 10^{8}$, and $10^{7}$ and the shelf life until the 20th day even some units until the 30th day. The encapsulation of Cuko pempek probiotic with storage at temperature of $27^{\circ} \mathrm{C}$ produced viability with the average number of cells reaching the range of $10^{9}, 10^{8}$, and $10^{7}$ and the shelf life until the 10th day even some units reaching the 20th day, but in the 8th day there was contamination in 5 experimental units, on the 10th day increased 5 contaminated units, and on the 12th day increased 3 units and on the 13th day occurred Sacharomyces contaminant on all experimental units.
\end{abstract}

Keywords-Encapsulation Probiotic, BAL, Cuko pempek.

\section{INTRODUCTION}

Pempek is a typical culinary Palembang, South Sumatra, Indonesia, made from wheat flour and tapioca, and fish. At this time it has become a culinary industry that development so rapidly therefore must be balanced with the provision of equipment distribution and presentation of a safety, healthy, and comfortable. Cuko pempek is a companion sauce to eat pempek. But Cuko pempek has specific characteristics, especially its cuka acid content, tooth decay (dental caries). This is in line with those proposed by Hoppenbrouwers and Driessens (1988) that acetic acid damages teeth twice as strongly of lactic acid. In addition acetic acid is anti-microbial (Lodovico et al., 2002; Snyder, 1997).

However, the anti-microbial characteristic possessed by Cuko pempek components that is capsaicin and alisin include weak category (Skrinjar and Nemet, 2009). Although, Zeyrek and Oguz, (2005) states, capsaicin can act as an effective bactericide. But the study of Farag et al., 1995 concluded that capsaicin from irradiated chilies was still overgrown with $4,2 \times 10^{3} / \mathrm{g} ; 14.3 \times 10^{3} / \mathrm{g}$; and $9,2 \times 10^{5} / \mathrm{g}$.

Cuko pempek is a food product that has potential to be functional food by making Cuko pempek probiotik (Dunne et al., 2001). Cuko pempek probiotic is cuko pempek containing BAL, and is expected to improve its functionality (Gardiner et al., 2001; Naito et al., 2008). Probiotics are supplementary foods that contain living micro-organisms that provide either human or animal host benefits by balancing the microorganisms in the digestive tract (Fuller, 1989). Further Senok et al., (2005) probiotics are living microorganisms when arranged in certain amounts will provide benefits for the health of its host.

Encapsulation is the process of forming a matrixshaped layer in which the inner-shaped interior resembles a capsule wall acting as a cloaking (Vidhyalakshmi et al., 2009). Gbassi and Vandamme (2012) call the term Probiotic Encapsulation Technology (PET), in which microbes can be widely immobilized using semipermiabel and biocompatible materials that govern the delivery of microbial cells. (Vidhyalakshmi et al., 2009) encapsulation tends to stabilize cells, potentially increasing cell viability and stability during production, storage, and handling.

BAL encapsulation techniques use phase separation techniques from Sheu and Marshall (1993) and use alginate ingredients (Anal and Singh, 2007) were selected to conduct a study of Cuko pempek probiotic.

\section{MATERIALS AND METHODS Lactic Acid Bacteria and Media}

L. bulgaricus and $S$. thermopylus were obtained from Balai Besar Vateriner Bogor. Lactobacilus was transferred to media of broth MRSAgar while Streptococus to media of broth Blood Agar Base. Then spread in the media agar of petri dish and incubated at $37^{\circ} \mathrm{C}$. BAL was harvested after 18 hours incubation to obtain a BAL culture concentration with a range of $10^{11} \mathrm{sel} / \mathrm{mL}$.

\section{Preparation of BAL Encapsulation}

The preparation of encapsulation used alginate natrum (Sheu and Marshall, 1993; Sultana et al., 2000) was $1 \%\left(\mathrm{~A}_{1}\right), 2 \%\left(\mathrm{~A}_{2}\right)$, and $3 \%\left(\mathrm{~A}_{3}\right)$ then mixed with BAL $L$. 
bulgaricus $\left(\mathrm{B}_{1}\right)$ and $S$. thermopylus $\left(\mathrm{B}_{2}\right)$ culture solution with 4: 1 ratio. After a flat stirring, the mixture was dropped using a $5 \mathrm{~mL}$ syringe into a $0.2 \%$ tween 80 solution in vegetable oil in a $1000 \mathrm{~mL}$ beaker glass. It was then poured $0.05 \mathrm{M} \mathrm{CaCl}$ solution as much as $250 \mathrm{~mL}$ rapidly through the edge of the glass wall and left for 30 minutes. The capsule granules would descend and the tween 80 solution, the vegetable oil and the remaining $\mathrm{CaCl}$ solution were removed by pouring slowly. The capsule granules were centrifuged at 350x for 15 minutes and then poured into a filter dish and washed with aquades. The preparation of Probiotic encapsulation was with three replications.

\section{The Preparation of Cuko pempek}

The preparation of Cuko pempek was according to ID (2012), brown sugar, garlic, cayenne and red chili mashed, and salt. Sour source was used yakult. Chili and salt blend and then mixed yakult and fermented for one week ( 7 days). Then water and sugar were heated to boil, removed and filtered. Then the fermented chili and yakult were fed into the filtered sugar water mixture, plus the fine garlic. The mixture was heated to boiling and cooled, then Cuko pempek was produced.

\section{The Preparation of Encapsulation of probiotic Cuko pempek}

$500 \mathrm{~mL}$ cuko pempek put in a container of plastic cans size $2000 \mathrm{~mL}$ as much as the amount of treatment with three replications. Then encapsulation probiotic BAL inserted into Cuko pempek. Some were stored at a temperature of $12^{\circ} \mathrm{C}$ and some were at temperature of $27^{\circ} \mathrm{C}$.

\section{Observation of viability Encapsulation of probiotic Cuko pempek}

Proactive observation of probiotic Cuko pempek encapsulation during storage on 1st day, 10th day, 20th day, and 30th day. Other parameters; shelf life and $\mathrm{pH}$ based on time.

\section{RESULTS AND DISCUSSION} A. BAL Viability of Cuko Pempek in Cold Temperature of $12^{\circ} \mathrm{C}$

The results of diversity analysis of encapsulation of probiotic Cuko pempek at storage temperature of $12^{\circ} \mathrm{C}$, that alginate concentration, BAL type, interaction, and treatment combination had no significant effect on BAL cell viability. While the group was very significant effect. This meant that alginate concentration did not affect BAL cell viability and was reliable for the encapsulation of probiotic Cuko pempek (Sheu and Marshall, 1993; Lotus et al., 2000; Mokarram et al., 2009; Lotfipour et al., 2012; Wikstrom, 2013), as well as the types of BAL (Speck and Myers, 1946; Drakes et al., 2004; Denou et al., 2008; Jimenez et al., 2010). The average number of $\mathrm{BAL}$ cells on the first day was $10^{9}$ for $\mathrm{L}$. bulgaricus $\left(\mathrm{B}_{1}\right)$ and $10^{8}$ for $\mathrm{S}$. thermopylus $\left(\mathrm{B}_{2}\right)$, then the average number of $\mathrm{BAL}$ cells both $\mathrm{B}_{1}$ and $\mathrm{B}_{2}$ on the 10th day, the 20th day, and the 30th day is sequential $10^{8}, 10^{7}$ serta $10^{7}$ and $10^{6}$. The average number of BAL cells was eligible to act as probiotic requiring an average number of BAL cells before consumption of $10^{7}$. As, Ishibashi and Shimamur, 1993) suggests, called probiotic food, should contain probiotic cells before consumption of $\geq 10^{7}$ cells per gram or per-mL of the product. Meanwhile, Lee and Salminen, (1995) require for probiotic drink products to contain as big a cell $\geq 105$ per $\mathrm{mL}$ of product. While FAO/WHO, (2002) requires the number of probiotic cells before consumption by 106 - $107 \mathrm{CFU} / \mathrm{g}$ or CFU/mL.

For storage of Cuko Pempek at cold temperature of $12^{\circ} \mathrm{C}$, BAL viability decreased linearly in ten days observation down by one $\log$ as in $\mathrm{A}_{1} \mathrm{~B}_{1}, \mathrm{~A}_{2} \mathrm{~B}_{1}$, and $\mathrm{A}_{2} \mathrm{~B}_{2}$ was obtained on observation the 30th day of the average number of BAL cells by $10^{6}$. This was caused by two things, first, because the BAL cells were stored in calcium alginate capsules; second, BAL cells were better protected from less favorable environmental influences such as acidity, the presence of capsaicin components of chili and the alisin component of garlic. As Sheu and Marshall, (1993) assert that encapsulated BAL cells have viability for up to 2 weeks and their viability is $40-45 \%$ higher than un-encapsulated BAL cells; Sultana et al., (2000), Encapsulation improves viability for up to 8 weeks. Wikstrom, (2013), that encapsulation provides cell viability capability for long periods of time. Furthermore, Gbassi and Vandamme, (2012) there are two reasons for encapsulation, first, to ensure the viability of encapsulated probiotic cells; and second, to ensure the release of probiotic cells when consumed and within the digestive tract. On the other hand, Lotfipour et al., (2012) explains that BAL encapsulation made from alginate provides better viability in acidic conditions. This confirms why the viability of BAL cells in Cuko pempek encapsulation had good viability.

Pattern of BAL cell viability reduction that was encapsulated with calcium alginate ingredients in cold storage temperature of $12^{\circ} \mathrm{C}$, was shown in Figure 1 , that $\mathrm{A}^{3} \mathrm{~B}^{1}$ (alginate $3 \%$ and $\mathrm{L}$. bulgaricus) had the highest viability on average in the four consecutive observation points in sequence $4,60 \times 10^{9} ; 1,09 \times 10^{8} ; 4,96 \times 10^{6}$; and $2,43 \times 10^{7}$; while the lowest was in $\mathrm{A}^{1} \mathrm{~B}^{2}$ (alginate $1 \%$ and $S$. thermopylus) with average at the four in sequence $6,55 \times 10^{8}$; $4,07 \times 10^{7} ; 4,18 \times 10^{7}$; and $7,16 \times 10^{7}$. The average number of cells met the probiotic requirements before consumption. 


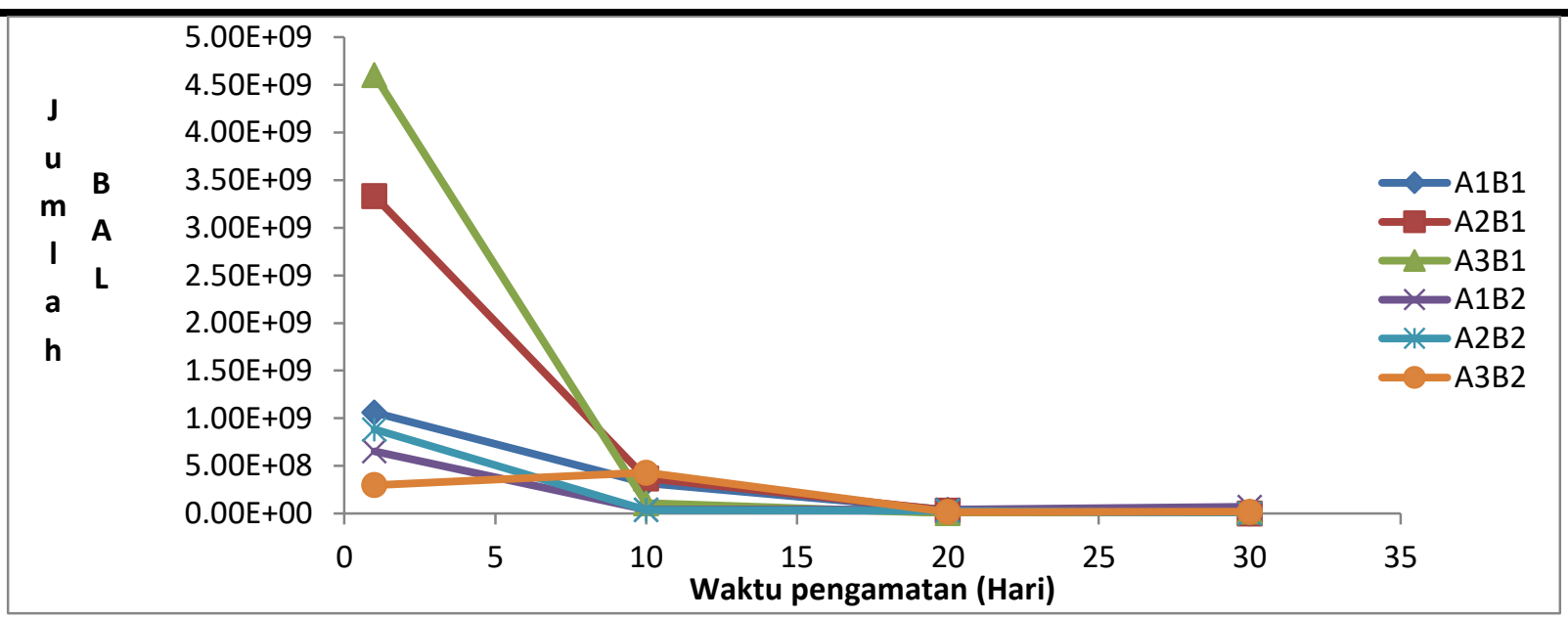

Fig.1: Graph of BAL Viability at Temperature Storage $12^{\circ} \mathrm{C}$

However, storage at cold temperatures of $12^{\circ} \mathrm{C}$ supported the viability of BAL cells. As the result of the research of Sheu and Marshall, (1993) that the encapsulation of BAL cells stored at cold temperatures had better viability. This pattern of decreased viability was similar to that described by Iyer and Kailasapathy, (2005) that BAL viability stored at cold temperatures decreases from $10^{8}$ to $10^{7}$ at the 2 nd week and to $10^{6}$ and $10^{7}$ at the 4 th week.

Furthermore, the results of the analysis of diversity with observations on the 1st day, 10th day, 20th day and 30th day, alginate concentration (A) and probiotic type (B) to $\mathrm{pH}$ encapsulation probiotik Cuko pempek at storage temperature of $12^{\circ} \mathrm{C}$, that the concentration alginate and its interactions had no significant effect, the type of probiotics, combinations of treatments and groups had a very significant effect. This was due to the presence of probiotic activity over time which results in changes in pH.Roberts et al., (1994) B. longum BB-79 encapsulation after 10 days had a pH of 3,9 - 4,2; Iyer and Kailaspathy, (2005) encapsulation of L. acidophilus had a pH of 4,6; L. plantarum pH 5,6 (Ayama et al., 2014).

To look at the degree of difference in each treatment that had a very significant effect on the $\mathrm{pH}$ of further tests, it was shown in Figure 2 that the $\mathrm{pH}$ encapsulation of probiotic Cuko pempek was very stable until the 10th day, and relatively stable until the 20th day and partly until the 30th day. This showed that during the period of time until the 10th day there was no significant microbiological activity, then until the 20th day there was little microbiological activity and increased activity until the 30th day. As expressed Robert et al., (1994) that in the encapsulation BAL probiotics begin to change $\mathrm{pH}$ after day 10.

\section{B. BAL Viability of Cuko Pempek at Room Temperature of $27^{\circ} \mathrm{C}$}

The result of diversity analysis of alginate concentration, BAL type, combination of treatment and its interaction had no significant effect on cell viability of BAL encapsulation of probiotic Cuko pempek at storage temperature of $27^{\circ} \mathrm{C}$, while the group was very significant. The viability on the first day was $10^{8}$, then the average number of BAL cells both L. bulgaricus (B1) and S. thermopylus $\left(\mathrm{B}_{2}\right)$ on the 10th, 20th, and 30th days was sequential $10^{7}, 10^{6}$ and $10^{5}$. This decrease in BAL cell viability appears to be associated with a decrease in $\mathrm{pH}$, since room temperature induced microbiological activity that affects pH. Noland and Aryana (2012) observes BAL viability in yogurt, $\mathrm{BAL}$ viability decreases when the $\mathrm{pH}$ falls below $\mathrm{pH}$ 4.3. However, the average number of BAL cells still qualifies as probiotics requiring a pre-consumption amount of $10^{7}$ (Ishibashi and Shimamur, 1993; Lee and Salminen, 1995; FAO / WHO, 2002). However, the number of eligible BAL cells was only until the 10th day.

Figure 3 about the decreased pattern of BAL cell viability of encapsulation of probiotic Cuko pempek at storage temperature of $27^{\circ} \mathrm{C}$, that $\mathrm{A}_{3} \mathrm{~B}_{1} \quad(3 \%$ alginate treatment and $L$. bulgaricus) had the highest viability and lowest available in $\mathrm{A}_{3} \mathrm{~B}_{1}(3 \%$ alginate treatment and $S$. thermopylus). The viability of $\mathrm{BAL}$ cells at storage temperature of $27^{\circ} \mathrm{C}$ occured in a lower log pattern decrease. This appears to be the condition of the room temperature caused the growth rate and activity of probiotic take place.

Furthermore, the results of the analysis of diversity, that the concentration of alginate, BAL type, combination of treatment and its interaction had no significant effect on $\mathrm{pH}$ encapsulation of probiotic Cuko pempek at storage temperature of $27^{\circ} \mathrm{C}$. To see the level of difference of group effect continued test shown in Figure 4. The $\mathrm{pH}$ pattern from high condition started $\mathrm{pH} 5$ on the 1st day, then fell to its lowest point on the 10th day of 3,73 and then up to the the 20th day of 3,87-3,9 and up again until the 30th day of 4 . But the increase did not go beyond $\mathrm{pH}$ on the first day. 


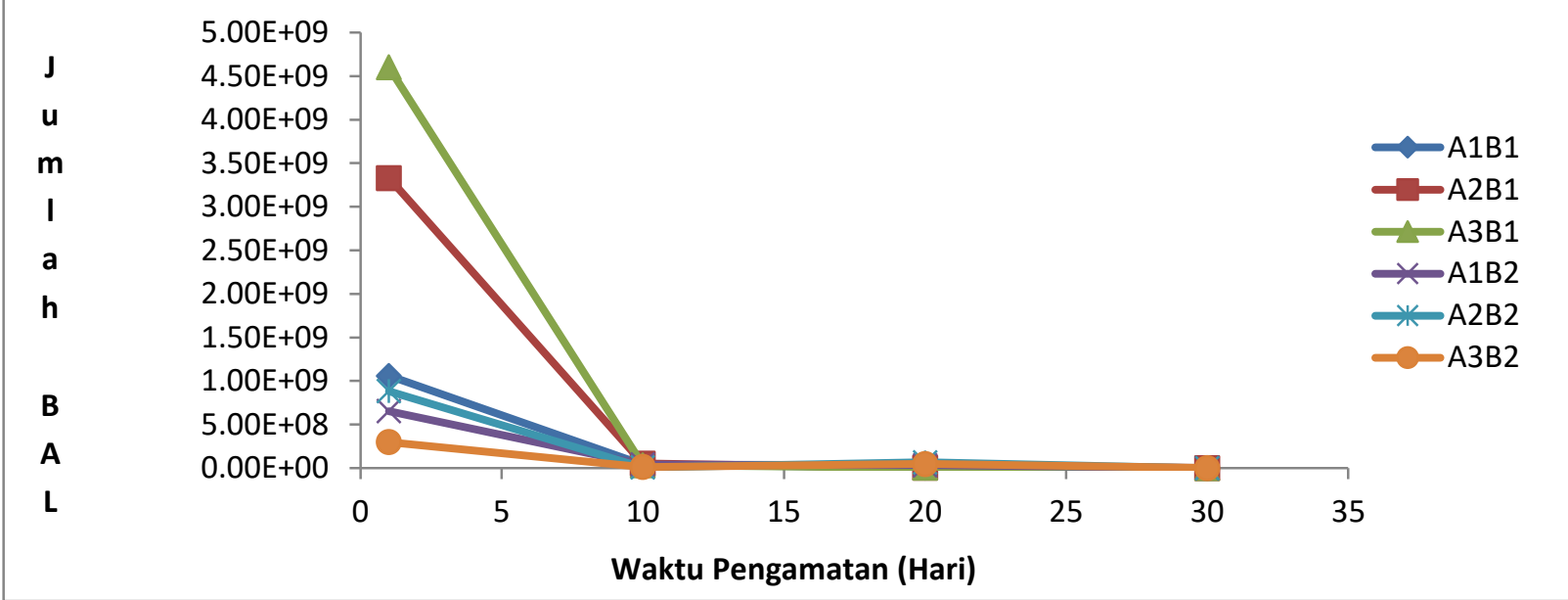

Picture 3. Graph of VAL Viability at storage temperature of $27^{\circ} \mathrm{C}$

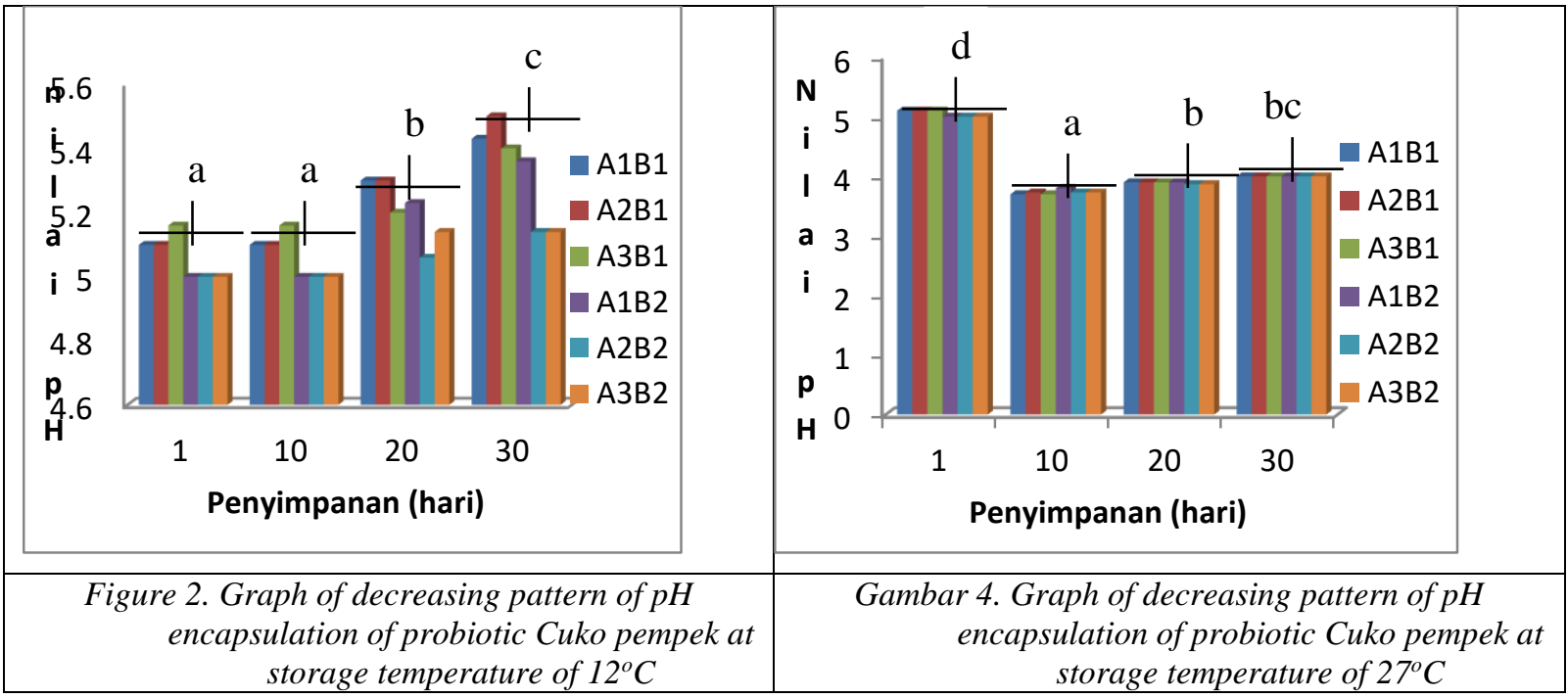

Unlike storage at cold temperatures of $12^{\circ} \mathrm{C}$, storage at temperature of $27^{\circ} \mathrm{C}$ in addition to caused the fermentative rates to produce decreasing $\mathrm{pH}$, also provided a great chance of contamination. On the 8th day, the units $A_{1} B_{1}(I), A_{1} B_{2}(I I)$, $\mathrm{A}_{2} \mathrm{~B}_{1}\left((\mathrm{I}), \mathrm{A}_{2} \mathrm{~B}_{1}\right.$ (III), and $\mathrm{A}_{3} \mathrm{~B}_{1}$ (III) were contaminated. Then on the 10th day the contamination increased in unit $\mathrm{A}_{1} \mathrm{~B}_{1}(\mathrm{III}), \mathrm{A}_{2} \mathrm{~B}_{1}(\mathrm{II}), \mathrm{A}_{3} \mathrm{~B}_{1}(\mathrm{II}), \mathrm{A}_{3} \mathrm{~B}_{1}(\mathrm{III})$, and $\mathrm{A}_{2} \mathrm{~B}_{2}(\mathrm{II})$, so that on the 10th day all experimental units using $L$. bulgaricus $\left(\mathrm{B}_{1}\right)$ had been contaminated Saccharomyces.

On the 12th day of the experimental unit using $S$. thermopillus $\left(\mathrm{B}_{2}\right)$ which on the 10th day was contaminated one of $A_{2} B_{2}(I I)$, three units were added, namely $A_{1} B_{2}(I)$, $A_{1} B_{2}(I I)$, and $A_{1} B_{2}(I I I)$. Then, on the 13th day all the experimental units were contaminated with Saccharomyces. This phenomenon indicated that acidic of Cuko pempek and stored at $27^{\circ} \mathrm{C}$ prone to contaminated and overgrown with
Sacharomyces. This confirms the results of the study of Narendranath et al. (2001), that Saccharomyces grows in a minimum medium containing acetic acid and lactic acid at temperature of $30^{\circ}$ C. Furthermore, Thomas et al. (2002) explains that Saccharomyces grows on a minimum medium containing lactic acid when its $\mathrm{pH}$ is 4.5 .

\section{CONCLUSIONS}

1. The encapsulation of probiotics Cuko pempek with storage temperature of $12^{\circ} \mathrm{C}$ produced viability with average number of cells reaching $10^{9}, 10^{8}$, and $10^{7}$ and shelf life until the 20th day and some units until the 30 th day, with a relatively constant $\mathrm{pH}$ ranging from $5,07-5,25$.

2. Encapsulation of Cuko pempek probiotic with storage temperature $27^{\circ} \mathrm{C}$ produced viability with average 
number of cells reaching $10^{8}, 10^{7}$, dan $10^{6}$ and shelf life up to the 10th day and some units reaching the 20th day, with decreasing $\mathrm{pH}$ from the 1 st day, the $10^{\text {th }}$ day, the 20th day and the 30th consecutive day $\mathrm{pH} 5,0-5,1$; pH 3,70 - 3,80; pH 3,87-9,0; and pH 4 .

3. For encapsulation of probiotic Cuko pempek with storage temperature of $27^{\circ} \mathrm{C}$ on the 8th day arose contaminant at 5 unit experiment, on the 10th day added 5 unit and on the 12th day arose in three other unit and on the 13th day arose contaminant in the form Sacharomyces on all experimental units.

\section{ACKNOWLEDGMENTS}

This Doctoral Dissertation of Grant Research was conducted due to a grant research from Sim-Litabmas Dirjen Dikti Kemendikbud RI fiscal year 2013-2014.

\section{REFERENCES}

[1] Anal, A. K.andH. Singh. 2007. Recent advances in microencapsulation of probiotics for industrial applications and targeted delivery. Food Science \& Technology 18: $240-251$.

[2] Ayama, H., P. Sumpavapol, dan S. Chanthachum. 2014. Effect of encapsulation of selected probiotic cell on survivalin simulated gastrointestinal tract condition. Songklanakarin J. Sci. Technol.36 (3): 291-299

[3] Denou, E., R.D. Pridmore, B. Berger, J.M. Panoff,F. Arigoni, and H. Bru“ssow. 2008.Identification of Genes Associated with the Long-Gut-Persistence Phenotype of the Probiotic Lactobacillus johnsonii Strain NCC533 Using a Combination of Genomics and Transcriptome Analysis.J. of Bacteriol., 190(9): 3161-3168.

[4] Drakes, M., T. Blanchard, and S. Czinn. 2004. Bacterial Probiotic Modulation of Dendritic Cells. Infectionand Immunity, 72(6): 3299-3309.

[5] Dunne, C., L. O’Mahony, L. Murphy, G. Thornton, D. Morrissey, S. O’Halloran, M. Feeney, S. Flynn, G. Fitzgerald, C. Daly, B. Kiely, G.C. O'Sullivan, F. Shanahan, and J.K. Collins. 2001. In vitro selection criteria for probiotic bacteria of human origin: correlation with in vivo findings $1-4$. Am J. Clin Nutr, 73(suppl):386S-392S.

[6] Farag, S. D. A., N. H. Aziz and S. A. Attia. 1995. Effect of irradiation on the microbiological status and flavouring materials of selected spices. Zeitschrift für Lebensmitteluntersuchung und -Forschung A, 201 (3): 283-288

[7] Food and Agriculture Organization/World Health Organization (FAO/WHO), 2002. Guidelines for the evaluation of probiotics in food, Report of a Joint FAO/WHO Working Group on Drafting Guidelines for the Evaluation of Probiotics in Food, London, Ontario, Canada. (http://ftp.fao.org/es/esn/ food/wgreport2.pdf).

[8] Fuller, R. 1989. Probiotics in Man and Animals.Journal Applied Bacteriology,66 (5): 365 - 378.
[9] Gardiner, G.E., C. Heinemann, M.L. Baroja, A.W. Bruce, D. Beuerman, J. Madrenas, and G. Reid. 2002. Oral administration of the probiotic combination Lactobacillus rhamnosus GR-1 and L. fermentum $R C$ 14 forhuman intestinal applications. International Dairy Journal 12: 191-19.

[10] Gbassi, G. K. and T. Vandamme. 2012.Probiotic Encapsulation Technology: From Microencapsulation to Release into the Gut. Pharmaceutics, 4: 149-163.

[11] Hoppenbrouwers, P.M.M. and F.C.M. Driessens. 1988. The Effect of Lactic and Acetic acid on the Formation of Artificial Caries Lesions. Juornal Dental Research 67 (12): 1466 - 1467.

[12] ID. 2012. Cara Pembuatan Cuko Pempek (Wawancara dengan pengrajin pempek di Palembang) Wawancara dilakukan pada Kamis tanggal 26 April 2012.

[13] Ishibashi N, and S. Shimamur. 1993.Bifidobacteria: research and development in Japan. Food Technol 47:126-35.

[14] Iyer, C., danK. Kailasapathy. 2005. Effect of Coencapsulation of Probiotics withPrebiotics on Increasing the Viability ofEncapsulated Bacteria under In Vitro Acidicand Bile Salt Conditions and in Yogurt. J. Food Science, 70(1): 18-23.

[15] Jime'nez, E., R. Martín, A. Maldonado, V. Martín, A.G. de Segura,L. Ferna'ndez, and J. M. Rodríguez. 2010.Complete Genome Sequence of Lactobacillus salivarius CECT 5713, aProbiotic Strain Isolated from Human Milk and Infant Feces. J. of Bacteriol, 192(19): 5266-5267.

[16] Lee Y.K., and S. Salminen. 1995. The coming of age of probiotics. Trends Food Sci Technol (6) :241-5.

[17]Lotfipour, F., S. Mirzaeei, andM. Maghsoodi. 2012.Preparation and Characterization of Alginate andPsyllium Beads Containing Lactobacillus acidophilus. The ScientificWorld Journal (2012): 1 - 8 .

[18]Ludovico, P., F. Sansonetty, M. T. Silva, and M. CorteReal. 2003. Acetic acid induces a programmed cell death process in the food spoilage yeast Zygosaccharomyces bailii. FEMS Yeast Research 3: 91 $-96$.

[19] Mokarram, R.R., S.A. Mortazavi, M.B.H. Najafi, and F. Shahidi. 2009.The influence of multi stage alginate coating on survivability of potentialprobiotic bacteria in simulated gastric and intestinal juice.Food Research International 42 (2009): 1040-1045.

[20] Naito, S., H. Koga, A. Yamaguchi, N. Fujimoto, Y. Hasui,H. Kuramoto, A. Iguchi and N. Kinukawa. 2008. Prevention of Recurrence With Epirubicin and Lactobacillus Casei After Transurethral Resection of Bladder Cancer. The Journal of Urology, (179): 485490.

[21] Narendranath, N.V., K.C. Thomas, and W.M. Ingledew. 2001. Effects of acetic acid and lactic acid on the growth of Saccharomyces cerevisiae in a minimal medium.J. Industrial Microbiol and Biotech. 26: 171177. 
[22] Noland, E., andK.J. Aryana. 2012. Influence of MicroEncapsulated Probiotic Lactobacillus acidophilus R0052 on the Characteristics of Plain Yogurt. Advances in Microbiology, 2012(2): 364-367.

[23] Roberts, C.M., W.F. Fett, S.F. Osman, C, Wijey, J.V. O’Connor, dan D.G. Hoover. 1994. Exopolisachararide production by Bifidobacterium longum BB-79. 6144.

[24] Senok, A. C., A. Y. Ismaeel, and G. A. Botta.2005. Probiotics: facts and myths. Clin.Microbiol. Infect. 11: 958-966.

[25] Sheu, T.Y. and Marshall, R.T. 1993. Microencapsulation of Lactobacilli in Calcium Alginate Gels.Journal Food Science. 54 (3): 557 - 561.

[26] Škrinjar, M. M. and N. T. Nemet. 2009. Antimicrobial Effects of Spices and Herbs Essensial Oils. APTEFF, 40: $195-209$.

[27] Snyder, O. P. 1997. Antimicrobial Effects of Spices and Herbs. (online) http://www.hitm.com/Documents/Spices.html Diakses pada Senin, 23 Januari 2012.Speck, M.L. and R.P. Myers. 1946. The Viability of Dried Skim-Milk Culture of Lactobacillus bulgaricus as Affected By The Temperature of Reconstitution. Journal Dairy Science, 657 - 663.

[28] Sultana, K., G. Godward, N. Reynolds, R. Arumugaswamy, P. Peiris, and K. Kailasapathy. 2000. Encapsulation of probiotic bacteria with alginatestarch and evaluation of survival in simulated gastrointestinal conditions and in yoghurt. International J. of Food Microbiol 62 (2000) 47-55.

[29] Thomas, K.C., S. H. Hynes, and W. M. Ingledew. 2002. Influence of Medium Buffering Capacity on Inhibition ofSaccharomyces cerevisiae Growth by Acetic and Lactic Acids. J. Applied and Environmental Microbiol, 68(4): 1616-1623.

[30] Vidhyalakshmi, R., R. Bhakyaraj and R.S. Subhasree. 2009. Encapsulation "The Future of Probiotics"-A Review. Adv in Biol Research 3 (3-4): 96103.Wikstrom, J. 2013. Alginate-based microencapsulation and lyophilizationofhuman retinal pigment epithelial cell line (ARPE-19) for celltherapy.Centre for Drug Research Division of Biopharmaceutics and Pharmacokinetics Faculty of Pharmacy University of Helsinki Finland. (on line), https://helda.helsinki.fi/bitstream/handle/10138/38293/a lginate.pdf?sequence $=1$ Diakses hari Kamis tanggal 6 November 2014.

[31]Zeyrek, F. Y. and E. Oguz. 2005. In Vitro Activity of Capsaicin Against Helicobacter pylori. Annal of Microb, 55 (2): 125 - 127. 